\title{
The Problem of First-Year Seminars: Risking Disengagement Through Market- place Ideals
}

Sarah Hickinbottom-Brawn

David P. Burns

Kwantlen Polytechnic University

\begin{abstract}
First-year seminars (FYS) have become increasingly prevalent in North American postsecondary institutions. The popularity of such initiatives owes much to the belief that providing unprepared students general life and academic skills can bolster engagement and thereby improve retention. In this paper we argue that, despite their good intentions, many FYS actually perpetuate the kind of disengagement they were designed to alleviate due to their reliance on a narrow, instrumental view of education. To demonstrate, we briefly outline the history and curricula of the FYS movement to draw attention to its dependence on marketplace ideals, rationales, and strategies. We demonstrate some of the ways this vision of education impoverishes the university experience and suggest that, in order to be robust, FYS must focus first and foremost on cultivating rich understandings of the broader purposes of higher education and its relation to the good life, both for and beyond one's own fulfillment.
\end{abstract}

\section{Résumé}

Les séminaires de première année sont devenus de plus en plus répandus dans les énstitutions d post-secondaires en Amérique du Nord. La popularité de telles initiatives doit beaucoup à l'idée que le fait de fournir des aptitudes générales et académiques aux étudiants non préparés peut renforcer leur engagement et ainsi améliorer leur taux de rétention. Dans cet article, nous soutenons que, malgré leurs bonnes intentions, beaucoup de sention. Dans cet aère année perpétuent le même genre de désengagement qu'ils essaient 
d'atténuer en raison de leur dépendance envers une vision instrumentale mais étroite de l'éducation. Pour le démontrer, nous décrivons brièvement l'histoire et les programmes de ce mouvement qui vise à attirer l'attention sur sa dépendance à l'égard des idéaux de marché, des justifications et des stratégies. Nous démontrons quelques-unes des façons par lesquelles cette vision de l'éducation appauvrit l'expérience universitaire et nous suggérons que pour être robustes, les séminaires de première année doivent d'abord se concentrer à cultiver la richesse de compréhension des objectifs plus larges de l'enseignement supérieur et de sa relation au bien-vivre, pour la r ur n-viv personnelle des étudiants et au-delà.

Over the past few decades, the notion that freshmen are unprepared for the rigours of postsecondary education has become increasingly prevalent throughout North American institutions of higher learning. Critiques (e.g., Cote \& Allahar, 2007) abound outlining the various ways in which contemporary university students' abilities to read, write, speak, and think logically, along with their willingness to put in the effort to do so, appear to be in short supply when compared to previous generations. As a side effect of this perception, many who work in postsecondary environments feel caught in a perplexing dilemma of failing, and perhaps losing, the students who constitute their enrolment-and, by extension, their livelihoods-versus compromising academic standards to accommodate these seemingly widespread deficits.

First-year seminars (FYS) have become one of the most popular efforts to combat this perceived trend of declining student abilities and motivation. Devised to address the needs of what is frequently referred to as the "unprepared learner," FYS aim to increase recruitment and retention by providing the necessary foundations for student success. The content of these seminars generally takes one of two forms. The first involves training students in a variety of skills associated with high academic achievement (e.g., time management, study skills, essay writing, interpersonal skills, stress management, career exploration) (see, e.g., Clark \& Cundiff, 2011). The second, which frequently encompasses the kind of skills training characteristic of the first, involves focusing on a particular topic presumed to appeal to a broad array of students (e.g., "The real CSI," "Make me laugh: Theory, practice, and enjoyment of comedy," "Social problems in cinema") in an attempt to pique academic interest more generally (e.g., Jessup-Anger, 2011).

These efforts to strengthen student readiness and interest are admirable and, in our view, warranted. Nonetheless, the rapidity with which the FYS movement has spread, combined with the general skills-based content of these courses, suggest a need to pause and consider what we, as educators, most want to achieve through this kind of programming. The increase in student enrolment that led to the need for FYS owes much to rising credentialism in the workplace and the subsequent shift towards what educational scholars (e.g., Barrow, 1999; Love, 2008; Pring, 2004) refer to as a market view of education in which degrees are construed as means rather than ends. The impact of this view has been threefold: 1) the role of the university has transformed from educating citizens to preparing workers; 2) students have developed increasingly instrumental expectations of what degrees should "get" them in terms of work and financial stability; and 3) grades 
have been inflated at every level of education to offer students a fighting chance at making a living. The decline in student readiness and motivation, which FYS aim to rectify, is a consequence of these trends. Students are entering institutions at a higher rate than ever. Yet, "compared to past generations, millennials were given higher grades in high school for less effort; as a result, fewer have been seriously challenged to develop their intellects and associated motivations to understand the world in increasingly complex ways" (Cote \& Allahar, 2007, pp. 17-18).

While FYS are an important intervention to counter these trends, and it is likely some are both rigorous and successful in their aims, we are concerned that those focused primarily on capturing students through entertainment or through training in skills and strategies devised to achieve high grades and find employment as effortlessly and efficiently as possible risk perpetuating the very disengagement they seek to alleviate. To be clear, this is not to say skills should not be taught. Rather, it is to suggest that emphasis is misplaced when it is implied that education is not an opportunity in itself but rather a problem to be solved. Framing education as "a commodity, rather than a challenge or commitment" (Burston, 2007, para. 21), and educational success as simply a consequence of monitoring and managing oneself through strategies, further reinforces the notion that education is merely a hurdle to be jumped-a chore that one must endure-to get what one really wants (i.e., economic prosperity). It is, however, questionable whether such a perspective can inspire excitement about learning.

Ideally, programs aimed at increasing engagement would address central questions that reveal how education is both a means and an end (e.g., "what does it mean to be an educated person?"; "what form of knowledge students ought to obtain?"; "what is the purpose of higher education in democratic societies?"; and "how is education related to the good life?"). However, FYS proponents frequently overlook or underrepresent such questions, relying instead on the tacit, market-driven vision of university that dominates contemporary educational discourse.

To demonstrate this argument, we begin with a brief history and curricular analysis that highlights elements of the movement with which we are concerned-that is, those that embody a narrow, instrumental vision of university education as preparation for the marketplace. We will then elaborate an Aristotelian view of knowledge to chart the pernicious implications of the instrumentalist view for both student growth and faculty participation in FYS. We conclude with suggestions for how FYS might better achieve their goals.

\section{First-Year Seminars: History and Current Context}

The birth of the contemporary FYS movement is often traced to an incident at the University of South Carolina (USC) in the early 1970s (Hunter \& Murray, 2007). According to the USC website (n.d.), in 1972, then-president Thomas Jones created a University 101 seminar in response to a series of student riots concerning the Vietnam War, social injustice, and an array of local campus issues. The purpose of Jones's seminar was to reestablish trust and cooperation between students, staff, and faculty, as well as to increase positive attitudes and behaviours towards the institution, enhance retention, communicate the value of education, and improve teaching in undergraduate programs. Selected instructors were trained to deliver the seminar and, following its success, present it in the form of national courses so other institutions could replicate it on their own campuses. 
By 1986, interest in the program led USC to establish a National Research Center for the Freshman Year Experience to encourage research, publication, and the identification of "best practices," as well as training events and conferences.

Since its inception, the center has grown rapidly. It now produces an academic journal entitled The Journal of the First-Year Experience and Students in Transition, a monograph series, books, and training videos, as well as endorsements for numerous commercially available assessments. The scope of the center's focus has also expanded. With a name change to the National Resource Center for the First-Year Experience and Students in Transition (NRCFYEST), the center now focuses on assisting all students in transition. This includes students who are preparing to graduate and transition to the next phase of life and, more recently, students who struggle beyond their first year, as demonstrated by the release of the center's publication Helping Sophomores Succeed: Understanding and Improving the Second-Year Experience (Hunter et al., 2010).

Not surprisingly, the popularity of FYS has also expanded. Part of this growth is undoubtedly due to the unprecedented rise in postsecondary enrolments. The US-based National Center for Education Statistics (2008) reported that enrolment in degree-granting institutions skyrocketed from 2.9 million in 1990 to 4.7 million in 2007. As more and more institutions open their doors to students who might not have pursued higher education in the past or who would not have been accepted to do so, the need to service "first-generation," "non-traditional," and "unprepared" students has become increasingly salient. To this end, 89\% of all public institutions in America now offer remedial services in basic skills (e.g., reading, writing, math), and according to the 2012-2013 National Survey of First-Year Seminars (NRCFYEST, 2013), nearly 90\% of 896 institutions surveyed provide FYS for course credit, with many requiring most or all students to enroll.

While variations exist in FYS offerings between institutions (e.g., general versus discipline-specific or theme-based, credit versus non-credit), there are perhaps more commonalities. To begin, it is widely agreed that the purpose of FYS is to increase retention through bolstering student engagement and academic success. Rarely is academic success defined, yet outcome research implies that it involves retention (e.g., Friedman \& Marsh, 2009), satisfaction with postsecondary life (e.g., Hendel, 2006-2007; Strayhorn, 2009), a high grade point average (e.g., Jamelske, 2009), and the efficiency with which one advances towards degree completion (e.g., Lang, 2007).

The means by which these goals are achieved are also consistent. According to the National Survey of First-Year Seminars (NRCFYEST, 2013), the top three objectives of North American FYS were to: 1) develop a connection with the institution; 2) provide orientation to campus resources and services; and 3) develop academic skills.

A review of popular FYS textbooks, such as Keys to Success (Carter, Bishop, Kravits, \& Maurin, 2010), Thriving in College and Beyond (Cuseo, Thompson, \& Fecas, 2008), and Becoming a Master Student (Ellis, 1998), suggests similar priorities. Five common themes stand out, each justified by psychological research demonstrating their connection to retention and academic success. First, FYS texts generally begin by reviewing the instrumental benefits of higher education. For example, in a section entitled "Education's worth it...and you can pay for it" (pp. 20-21), Ellis (1998) claims that education is "one of the safest investments possible. When you are clear about what you want, education is usually a way to get it" (p. 20). He goes on to say: 
Money invested in land, gold, oil, or stocks can easily be lost. When you invest in yourself, you can't lose. Over a lifetime, a college or university graduate can expect to earn about $\$ 1$ million more on the average than a person whose education stops with high school. Education also pays off in job promotions and career satisfaction. The list of possible benefits continues. Higher education has been suggested as the source of everything from better health to happier marriages. (p. 20)

Other commonly noted benefits include: improved self-knowledge; critical-thinking skills; appreciation of other cultures and world issues; social skills; spiritual and moral growth; and the acquisition of positive self-beliefs and personal habits (e.g., becoming self-motivated, self-disciplined, self-reliant, self-sufficient, self-confident, etc.) (Carter et al., 2010; Cuseo et al., 2008).

The second theme common to FYS involves information and activities aimed to bolster self-exploration and personal development. Such content generally includes knowledge of student service resources and normalization of help-seeking behaviours, as well as skills and strategies for stress management, interpersonal communication, self-monitoring, time management, and money management; some texts (e.g., Cuseo et al., 2008; Ellis, 1998) include additional information on nutrition management and exercise management. Upon introducing each topic, texts typically draw on examples and data from psychological research to demonstrate the utility of these skills and strategies for both improving academic performance and achieving success beyond the confines of postsecondary studies. For instance, following a discussion on the need for modern professionals to balance multiple responsibilities in order to achieve personal success, Cuseo and his colleagues (2008) state, "For these reasons, time management should be viewed not only as a college-success strategy, but also as a life-management strategy and lifesuccess skill” (p. 321).

A third, somewhat related, content area involves information and exercises associated with choosing a career and, by deduction, a program of study. These exercises generally follow the traditional three-step model of career counselling set out by Frank Parsons in 1909: know oneself, know the market, make a decision. Students are encouraged to engage in reflection, undergo personality and skill assessments, learn about careers, and attain experience through volunteering, work, or co-op programs, so they may make rational, informed decisions about their futures. Reading the information regarding such decisions, one quickly picks up a particular sense of urgency in the call to action. For instance, Cuseo et al. (2008) state that "career planning should begin in the first year of college" (p. 286), while Ellis (1998) notes that "career planning is a choice, not a discovery" (p. 332). Moreover, students are encouraged to monitor, through portfolios and journals, their development through education at all times and in relation to their occupational goals. As Cuseo et al. advise, "[D]on't overlook the fact that learning skills are also earning skills. The skills you are acquiring in college may appear to be just academic-performance skills, but they are also career-performance skills" (p. 301).

Lastly, comprising the lion's share of FYS curriculum is content aimed at helping individuals become better students through academic skills training. Strategies and techniques for time management, money management, note taking, listening, reading, study- 
ing, researching, writing, thinking, communicating, presenting, and decision making form the core of mainstream FYS (e.g., Chambers, Smith, Orvis, \& Caplinger, 2013; Clark \& Cundiff, 2011).

In sum, despite variation in the particulars, there is general consistency between institutions about the assumptions, means, and goals of FYS. Specifically, it is presumed that all students can become "master students" capable of high levels of academic achievement, satisfaction, and vocational success through learning and utilizing skills aimed at developing self-discipline, self-management, and self-regulation. For institutions, the success of these endeavours is defined in terms of retention. For students, success involves obtaining good grades in as stress-free and enjoyable a manner as possible, in order to complete their degrees efficiently and achieve satisfying and well-paying employment.

\section{First-Year Seminars and the Language of the Marketplace}

At first blush, the goals of FYS seem worthwhile and appropriate. With respect to the institutional position, for instance, it is the case that education is a business, of a sort, and that high levels of recruitment and retention are necessary for it to function. Moreover, if large numbers of students enter postsecondary education lacking the very basic academic and personal skills necessary to complete courses, then it is arguably unethical for institutions to accept their tuition without having supports in place.

What students hope to achieve through participating in FYS also seems reasonable. After all, it is difficult to imagine a student for whom receiving low grades would be preferable to receiving high ones, or who would opt to struggle unnecessarily if easily acquired skills and strategies were available that could ensure success. Likewise, as tuition skyrockets, it is hard to imagine how any but the most privileged student could advance through a degree without some concern over whether it is worth the investment. Students want their degrees to be useful, as opposed to useless, and so they should.

Nonetheless, there are a number of dangers in construing the goals of higher education to be reducible to a collection of skills, efficiencies, and instrumental gains.

While one might argue that this kind of skills training serves the broad purposes of education, such claims rely on what philosophers (e.g., Barrow, 1999) refer to as the "generic fallacy," in which it is assumed that skills are generic and can be applied in any context. For instance, most would agree that there is great value in cultivating a citizenry that is capable of thinking critically. But what is often overlooked is that thinking critically requires not only an understanding of logical reasoning, but also a certain kind of disposition, as well as a clear understanding of the fundamental concepts and methods of the domain about which one is to think critically. One cannot think critically about politics, for example, without knowing about the political arena and its basic structure. Thinking critically is not a generic skill. It is a complex ability that requires both immersion in a subject and the character virtues associated with scholarly engagement.

Admittedly, terms such as skills and strategies apply in some sense to education. But they primarily constitute the language of the marketplace, and their dominance in programs designed to introduce students to the culture of higher education is deeply troubling. To be clear, FYS are not the only place in academia where the language of the marketplace enjoys an audience. On the contrary, FYS have simply appropriated what many educational critics (e.g., Barrow, 1999; Love, 2008; Pring, 2001, 2004) have observed as 
a broader trend of universities becoming reorganized along business lines in which they are valued primarily in economic terms. Increasingly, students are thought of as "consumers," institutions as "service providers," and educators as "deliverers of curriculum," while programs are valued less for their educational merits than for the extent to which they attract funding through research grants and/or tuition. ${ }^{1}$ As marketing departments have become a common feature of the higher education landscape, so too has the presumably appealing message "Our students get jobs!" It is a message that both draws on and contributes to the prevailing view that the primary function of higher education is to teach skills for employability-a view now so pervasive that some would argue it is the university's only function (see Love, 2008).

While this brand of economic instrumentalism is not entirely wrong per se, its dominance in current discourse conceals the broader, and arguably more engaging, purposes of higher education. Educational scholars have long argued that the purposes of education are manifold and involve, among other things, acquisition and generation of knowledge, cultivation of intellectual virtues/dispositions, sustenance of the kind of educated populace necessary to maintain a thriving democracy (including a nod to both responsible citizenship and education's more subversive functions in challenging the status quo), and refinement of the abilities to think logically and critically.

Yet, increasingly, the value of this kind of well-rounded, challenging education is being exchanged for a narrow, vocational model. In this view, everyone who desires a comfortable standard of living must go to university as soon as possible. Once admitted, students should quickly select a major and proceed through their degrees as efficiently as possible so they can get out of university, get a job, and make money-preferably a lot of it. While higher ideals about learning and citizenship are never fully out of the conversation, they have receded far into the background and are often dismissed as elitist by those who emphasize the value of education's vocational purposes. This particular form of the vocational model can be accurately labelled the instrumental view of higher education.

Of course, it is possible that some proponents of FYS would argue that they in fact do discuss broader educational aims with their students. Given the variation in FYS across institutions, it is possible that they do just this. However, the strong emphasis on skills in the FYS literature, be they academic, social, or personal, implies that, for the most part, such messages receive short shrift. For instance, a cursory review of three leading FYS textbooks (see Table 1) reveals that they devote little, if any, space to the topic of the value and ideals of higher education or what it means to be an educated person. Moreover, when the value of education is addressed, it is often solely in terms of monetary gain. For instance, Carter et al. (2010) advise that "to make the most of college, first understand its value. College or university is the ideal time to acquire skills that will serve you in the global marketplace" (p. 4). They go on to detail how the "employability skills" (p. 7) one develops through higher education are necessary for reaching one's "life success goals" and represent what is needed "to enter, stay in, and progress in the world of work" (p. 5). Thus, while it is possible that some FYS address the broad purposes of education, there would seem to be a risk that these grander educational ideals could be overshadowed by more obviously instrumental lessons. 
Table 1.

FYS Textbooks

\begin{tabular}{lccc}
\hline Text & $\begin{array}{c}\text { Pages devoted to } \\
\text { broad purposes }\end{array}$ & $\begin{array}{c}\text { Pages devoted to } \\
\text { formal skills training }\end{array}$ & Total pages \\
\hline $\begin{array}{l}\text { Thriving in College and } \\
\text { Beyond (Cuseo et al., 2008) }\end{array}$ & 22 & 325 & 501 \\
$\begin{array}{l}\text { Keys to Success (Carter et al., } \\
\text { 2010) }\end{array}$ & 0 & 395 & 395 \\
$\begin{array}{l}\text { Becoming a Master Student } \\
\text { (Ellis, 1998) }\end{array}$ & 3 & 340 & 346 \\
\hline
\end{tabular}

Note: Additional pages in Thriving in College and Beyond focus on issues of drug and sex education.

\section{Consequences of the Instrumental View}

The privileging of the instrumental view, combined with its accompanying concealment of education's broader purposes, leads to a range of interrelated and unintentional consequences for FYS. Below we explore these problematic side-effects as they pertain to two categories: 1) the value of means over ends and 2) the impoverished view of pedagogy.

\section{The Value of Means Over Ends}

To understand fully the problematic implications of the instrumental vision of education underlying FYS we must go back to Aristotle's (trans. 1925) well-known work on the subject of knowledge; Nicomachean Ethics. There he draws distinctions between three broad forms of knowledge. Episteme, or scientific knowledge, refers to knowledge-about or knowledge that is universal and independent of context and experience. Techne, or technical skill, involves know-how and is concerned primarily with production and the proficient use of means for the attainment of pre-established ends. Phronesis, or practical wisdom, pertains to ethical decision-making and involves the ability to determine proper means and ends by considering both the particularities of specific situations and the generalities of what it is good to do and be.

Much FYS instruction clearly takes place within the realm of techne. When a student is called to demonstrate the ability to cite and reference sources, conduct library searches, record time use, and schedule future obligations, s/he is being asked to master a particular form of techne. The technical expert is not a master of ends per se but rather a master of the means by which one can realize a pre-established goal. The ends are presumed (in the case of FYS: work quickly, get high grades, get a good job). The struggle in techne, then, involves mastering means through experience and practice.

In contrast, it is impossible to speak of mastery with respect to phronesis. While phronesis is similar to techne in that both involve application and practical experience, phronesis is concerned with both means and ends, whereas techne is concerned only with the former. In other words, phronesis is concerned not only with "how" one does something, but also with "why" one would do it. As such, techne can be viewed in a formulaic manner, but phronesis cannot. 
The consideration of ends is central to how deeply one engages with a task. This point is made evident in a study by Pitts, White, and Harrison (1999) examining why faculty were skeptical about the effectiveness of remediation programs like FYS despite believing they were needed. All respondents noted problems in basic levels of student knowledge and skills. However, discussion of these deficits was consistently framed in affective, rather than technical, terms. More specifically, the general conviction was that students did not possess the proper disposition to learn; they lacked the right attitude and motivation. As one respondent noted, "students don't have that sense of wanting to learn just for the sake of learning" (p. 348). Rather, the attitude is "it's all for the money . . 'I'm going to school so I can get a good job and make lots of money" (p. 348). There was further concern that students constantly seek the easiest solution. As one respondent observed, "[s] tudents today are more prone to and adept at finding easy ways to get by ... rather than trying to become a more academically oriented person [and] start working toward a longterm solution to the problem" (p. 350). When FYS focus solely on skills training, they perpetuate this problem. When ends are tacitly assumed, that assumption tends to fall in line with the dominant instrumental view. The work itself becomes meaningless, and the student becomes disengaged. To see value in knowledge and in the process of obtaining it requires understanding that knowledge is an end in itself.

The consideration of ends is also key to understanding how and when to apply knowledge. This is particularly important given the concern that students often do not know how to apply their knowledge and skills outside of school. Woolfolk's (1998) example of a recent assertiveness training course graduate demonstrates this point. The assertiveness graduate may well have the skills to "stand up for his/her rights" but not necessarily the wisdom to apply these skills judiciously. Being properly assertive requires not only the know-how of skills, but also the knowledge of what it is appropriate to stand up for and to whom it is appropriate to stand up. As such, the proper application of assertiveness skills lies beyond the ken of simple formulae. What constitutes proper action in any situation can never be known fully in advance. In each case, the generalities of what it is good to do and be must be considered against the demands of the specific situation.

It should be unproblematic to expect universities to foster persons capable of this sort of knowledge. Yet, it is easy to see how this sort of vision appears prohibitively ambitious for many university educators. True growth into better, wiser, and more virtuous persons involves a complex, ongoing form of learning by individuals willing to tolerate ambiguity and engage deeply with matters at hand. Such a vision of education is engaging and worthwhile, but it is neither as efficient nor as straightforward as the market vision demands. Moreover, the formulae and certainties of techne are a comfort to overworked and inundated students, and this is often precisely what the customers-to use marketplace language-want. However, we believe this comfort is insufficient for educators to abandon the more ambitious objective of cultivating graduates who are certain kinds of persons (i.e., wise and virtuous). To do so we must find a way to promote, in FYS, concerns about why education is valuable in and of itself. As we discuss below, this would require placing questions of ends ahead of questions of means. 


\section{The Impoverished View of Pedagogy}

The illusion of straightforwardness implied by the instrumental view is also problematic in that it produces an impoverished view of pedagogy. To begin, when FYS are construed as skills training, this construal seriously reduces the requirements for who can "deliver" curriculum. ${ }^{2}$ To engage students in the university experience requires strong, knowledgeable, inspiring, and provocative faculty. Yet, if FYS are simply viewed as programs of decontextualized skills training, expertise in a scholarly discipline is not required. As Hunter and Murray (2007) argue, "The first-year experience movement opens a window of opportunity for student affairs professionals to extend their educational endeavors into the classroom, thus allowing entrance into segments of campus once reserved exclusively for faculty" (p. 25). From the instrumental training view of education, such a claim is sound. Anyone who knows the formula for the prescribed techniques can deliver the curriculum. Nothing more in terms of knowledge and experience is required. Just as the instrumental view frees students from having to meaningfully better themselves, so too does it free the FYS instructor from being a particular sort of academic. The distinction between the scholar and the administrative professional is thereby weakened, and higher education is, to the same extent, deprofessionalized.

Such a perspective diminishes not only the quality of what is taught but also how it is taught. Ideally, education of any sort should be seen as a shared experience between teacher and student that is focused on a particular form of personal growth. That growth comes from the way the educator brings the intellectual richness and rigour of his/her tradition into the classroom. When education is conceived of merely as deprofessionalized instrumental training, on the other hand, the emphasis shifts away from this growth.

As educational philosopher Richard Pring (2001) notes, "[o]nce the teacher 'delivers' someone else's curriculum with its precisely defined 'product,' there is little room for that transaction in which the teacher, rooted in a particular cultural tradition, responds to the needs of the learner" (p. 108). What occurs in such instances is not an examination of a history of understanding in a discipline, or a wondering together about questions that do not admit of a final answer (which could be said of many educational questions), but rather training seminars in which an "expert" delivers sets of steps to a "non-expert." The student need not meaningfully grow, and the educator need not bring much of his or her self or academic traditions to the classroom. This view, needless to say, is deeply impoverished, highly mechanical, and far from engaging.

\section{Conclusion}

Examining the academic literature about FYS yields the conclusion that while these seminars sometimes explore the broader purposes of higher education, the instrumental vision of higher education remains dominant. This view, built upon the language and values of the market, has an admittedly important role in universities. However, if the goal of education is to produce educated citizens, then instrumentalism should play a much smaller role than it currently does. Above, we have presented a brief sketch of how the instrumental view-by construing educational success as the mere mastery of formulaic approaches to learning and managing one's life that enable one to finish school efficiently and with as little struggle possible-narrows both the view of student growth and the role of educators in FYS. 
Postsecondary education has far more to offer than such a view suggests, and seminars designed to help students transition to university and become engaged in the process of their education should prepare them for considerably more inspired journeys. Doing so would require FYS to begin with and maintain a constant connection to questions about the proper ends of education: What is the purpose of higher education in democratic societies? What is the relation between education and the good life? How can being educated improve not only my life, but the lives of others? What are the qualities of an educated person? What enables one to cultivate that kind of disposition? How does/has education function/ed in other societies? How does it function here and now? In exploring these questions, students will come to find reasons to value education for what it gives them rather than what it gets them. In doing so, they will also develop a desire to learn whatever skills they need, in the same way a child who loves baseball will spend endless hours in a batting cage without prompting. They will do this because they see and value the purpose of what they are doing. Education will cease to be skills training and knowledge acquisition and instead become a moral practice. On this view, education is an activity in which the teacher is sharing in a moral enterprise, namely, the initiation of (usually) young people into a worthwhile way of seeing the world, of experiencing it, of relating to others in a more human and understanding way. In so doing, education becomes "a transaction between the impersonal world of ideas embodied within particular texts and artefacts and the personal world of the young person as he or she struggles to make sense, searches for value, engages in discovery, finds ideas worth striving for, encounters ideas" (Pring, 2001, p. 106).

Most educators recognize this struggle. Some might even suggest, as Pring (2002) has done elsewhere, that the practice of education is primarily concerned with this struggle. In the language of the marketplace, which values ease and efficiency, it is more palatably referred to as "engagement." Yet, if we are to engage, then we cannot rely on a view of education that aims primarily to ameliorate struggle. Rather, we must give students something worth struggling for and something they genuinely want to struggle with.

To do so, FYS curricula should be centered on the fundamental reasons for educating students-rather than on techniques for efficaciously completing educational experiences. The "value of college" should not merely be a preface introducing a long series of technical discussions about mnemonic devices and note-taking strategies. Rather, it should be the anchoring point of all FYS experiences. This means not only discussing the value of postsecondary education to society, or to one's career prospects, but also the ways in which one's day-to-day life in school can be understood and valued. It is in this context that academic skills can be made most meaningful and engaging. In addition, and by extension, FYS instructors must be ambassadors not just for academic skills but also for the philosophy of postsecondary education. FYS present a magnificent opportunity to frame and define postsecondary experiences. The quality of those experiences depends not just on the skills practiced within them, but on the life they are meant to help define. To ensure that FYS make the most of this opportunity, they must focus first and foremost on this task. 


\section{References}

Aristotle. (1925). The Nicomachean ethics (W. D. Ross, trans.). Oxford, UK: Oxford University Press. (Original work published $350 \mathrm{BC}$ ).

Barrow, R. (1999). The higher nonsense: Some persistent errors in educational thinking. Journal of Curriculum Studies, 31(2), 131-142.

Burston, D. (2007). Modes of authority and the crisis of higher education. Logos, 6(3). Retrieved from http://www.logosjournal.com/issue_6.3/burston.htm

Carter, C. J., Bishop, J., Kravits, S. L., \& Maurin, P. J. (2010). Keys to success: How to achieve your goals (5th Canadian ed.). Toronto, ON: Pearson.

Chambers, W. L., Smith, L. P., Orvis, J. N., \& Caplinger, C. (2013). Developing a topiccentered first-year seminar with an emphasis on information literacy at a large regional university. College \& Undergraduate Libraries, 2O(1), 52-71. doi:10.1080/10691316.20 13.761077

Clark, M. H., \& Cundiff, N. L. (2011). Assessing the effectiveness of a college freshman seminar using propensity score adjustments. Research In Higher Education, 52(6), 616639.

Cote, J., \& Allahar, A. L. (2007). Ivory tower blues: A university system in crisis. Toronto, ON: University of Toronto Press.

Cuseo, J., Thompson, A., \& Fecas, V. S. (2008). Thriving in college and beyond: Research-based strategies for academic and personal development. Dubuque, IA: Kendall Hunt.

Ellis, D. (1998). Becoming a master student (2nd Canadian ed.). Boston, MA: Houghton Mifflin.

Friedman, D., \& Marsh, E. G. (2009). What type of first-year seminar is most effective? A comparison of thematic seminars and college transition/success seminars. Journal of The First-Year Experience \& Students in Transition, 21(1), 29-42.

Hendel, D. D. (2006-2007). Efficacy of participating in a first-year seminar on student satisfaction and retention. Journal of College Student Retention, 8(4), 413-423.

Hunter, M. S., \& Murray, K. A. (2007). New frontiers for student affairs professionals: Teaching and the first-year experience. New Directions for Student Services, 117, 25-34.

Hunter, M. S., Tobolowsky, B. F., Gardner, J. N., Evenbeck, S. E., Pattengale, J. A., Shaller, M., \& Schreiner, L. A. (2010). Helping sophomores succeed: Understanding and improving the second-year experience. San Francisco, CA: Jossey-Bass.

Jamelske, E. (2009). Measuring the impact of a university first-year experience program on student GPA and retention. Higher Education, 57(3), 373-391.

Jessup-Anger, J. E. (2011). What's the point? An exploration of students' motivation to learn in a first-year seminar. The Journal of General Education, 6o(2), 101-116.

Lang, D. J. (2007). The impact of a first-year experience course on the academic performance, persistence, and graduation rates of first-semester college students at a public research university. Journal of The First-Year Experience \& Students in Transition, 19, 9-25. 
Lifton, D., Cohen, A., \& Schlesinger, W. (2007). Utilizing first-year curricula linkage to improve in-major persistence to graduation: Results from a four-year longitudinal study, fall 2000-spring 2004. Journal of College Student Retention: Research, Theory \& Practice, 9, 113-125.

Love, K. (2008). Higher education, pedagogy, and the "customerisation" of teaching and learning. Journal of Philosophy of Education, 42, 15-34.

National Center for Education Statistics. (2008). 2008 Digest Tables. Chapter 3: PostSecondary Education. Retrieved from http://nces.ed.gov/programs/ digest/2008menu_ tables.asp

NationalResourceCenterforFirst-YearExperienceandStudentsinTransition[NRCFYEST]. (2013). 2012-2013 National Survey of First-Year Seminars. Retrieved from http://sc.edu/ fye/research/surveys/survey_instruments/pdf/Executive_Summaries_2013_National_ Survey_FirstYearSeminars.pdf

Parsons, F. (1909). Choosing a vocation. Boston, MA: Houghton Mifflin.

Pitts, J. M., White, W. G., Jr., \& Harrison, A. B. (1999). Student academic unpreparedness: Effects on faculty. The Review of Higher Education, 22(4), 343-365.

Pring, R. (2001). Education as a moral practice. Journal of Moral Education, 30(2), 101-112.

Pring, R. (2002). The future curriculum-but don't forget the past. In M. Convey (Ed.), The school curriculum ten years hence: Providing effective teachers. An account of the Joint UCET/HMI Symposium held in Belfast, 10/11 December 2001. Occasional Paper No. 14. London, UK: Universities' Council for the Education of Teachers. Retrieved from http://www.ucet.ac.uk/387

Pring, R. (2004). The skills revolution. Oxford Review of Education, 30, 105-116.

Strayhorn, T. L. (2009). An examination of the impact of first-year seminars on correlates of college student retention. Journal of The First-Year Experience \& Students in Transition, 21, 9-27.

University of South Carolina. (n.d.). History of the first university seminar and the University 101 Program. Retrieved from http://www.sc.edu/univ101/aboutus/history. html

Woolfolk, R. L. (1998). Cure of souls: Science, values, and psychotherapy. San Francisco, CA: Jossey-Bass.

\section{Notes}

1 One indication of the extent to which this competition for student tuition has impacted thinking about FYS can be seen in the writings of Lifton, Cohen, and Schlesinger (2007), who argue that departments should adopt discipline-based FYS as "an antidote to the lure that other disciplines have in swaying students from their original choice of study" (p. 114).

2 It is worth noting here that "delivering curriculum" is philosophically incomprehensible if student growth is understood via phronesis (which, categorically, cannot be given or delivered). 


\section{Contact Information}

Sarah Hickinbottom-Brawn

Department of Educational Studies

Kwantlen Polytechnic University

sarah.hickinbottom@kpu.ca

Sarah Hickinbottom-Brawn, PhD (Educational Psychology, Simon Fraser University), is a faculty member in the Department of Educational Studies at Kwantlen Polytechnic University (KPU). Her background is in counselling and theoretical and philosophical psychology, and her scholarly work is focused on disclosing assumptions underlying everyday understandings regarding the good life and well-being, through historical, crosscultural, and philosophical investigations of psychological and educational concepts. In developing the first-year transition course at KPU, she was guided by the thought: If university is the answer, what was the question?

David P. Burns, PhD (Educational Policy Studies, University of Alberta), is a faculty member in the Department of Educational Studies at Kwantlen Polytechnic University. His background is in the philosophy of moral education, environmental education, science education, and social justice and diversity. He teaches a wide range of Educational Studies courses at KPU, including a first-year transition course. 